J. Dairy Sci. 100:3326-3326

https://doi.org/10.3168/jds.2017-100-4-3326

(c) American Dairy Science Association ${ }^{\circledR}, 2017$.

\title{
Corrigendum to "Proteomics method to quantify the percentage of cow, goat, and sheep milks in raw materials for dairy products" (J. Dairy Sci. 99:9483-9492)
}

\author{
Q. Chen, X. Ke, J. S. Zhang, S. Y. Lai, F. Fang, W. M. Mo, and Y. P. Ren
}

On page 9484 ("Sample Preparation and Tryptic Digestion") and page 9488 ("Optimization of Sample Preparation"), the incorrect reagent was mentioned. In both instances, "indoleacetic acid" should be "iodoacetamide."

\section{REFERENCES}

Chen, Q., X. Ke, J. S. Zhang, S. Y. Lai, F. Fang, W. M. Mo, and Y. P. Ren. 2016. Proteomics method to quantify the percentage of cow, goat, and sheep milks in raw materials for dairy products. J. Dairy Sci. 99(12):9483-9492. http://dx.doi.org/10.3168/jds.2015-10739. 